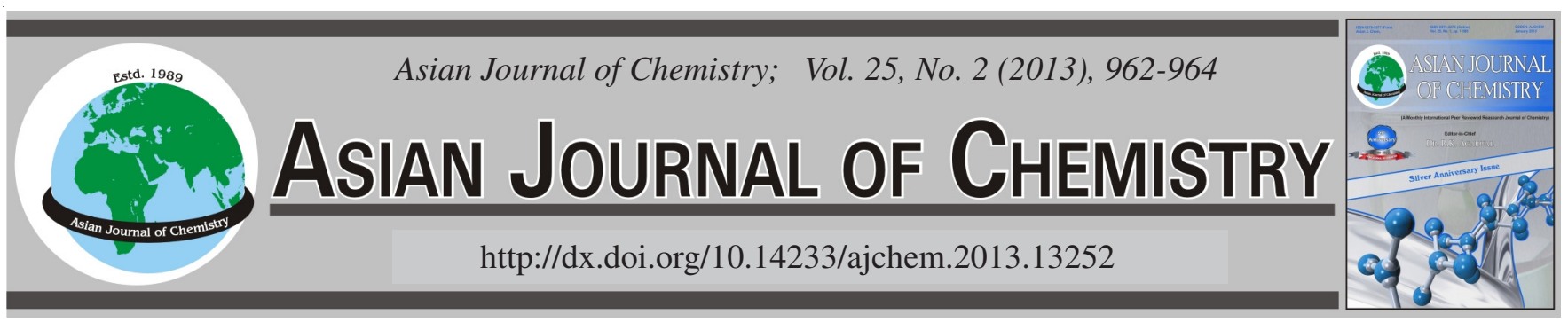

\title{
Synthesis of Derivatives of Di-butyldithiocarbamates
}

Kamal Khoudary ${ }^{1}$, Sobhi Mona², Mouhamad Matar ${ }^{2}$ and Samar Haffar ${ }^{1, *}$

${ }^{1}$ Department of Chemistry, Faculty of Science, University of Aleppo, Aleppo, Syria

${ }^{2}$ Department of Plant Protection, Faculty of Agriculture, University of Aleppo, Aleppo, Syria

*Corresponding author: Tel: +963 944856808; E-mail: samar81808@ @otmail.com

(Received: 14 December 2011;

Accepted: 27 August 2012)

AJC-12021

The sodium salt of dithiocarbamate (1a) is synthesized by reaction of dibutylamine with carbon disulfide and sodium hydroxide. Phenacyldibutyl-dithiocarbamate (1b) is prepared by reaction of dibutylamine with carbon disulfide and alkylating agent. The (1-benzoyl-2,2dibutylthio)vinyl dibutyl dithiocarbamates (1c) is prepared by dithiocarboxylation of (1b) under phase transfer conditions followed by butylation. All substance (1a), (1b) and (1c) are indentified by m.p., colour, ${ }^{1} \mathrm{H}$ NMR and IR spectra.

Key Words: Dithiocarbamates, Dibutylamine, Carbon disulfide, Fungicides, Herbicides.

\section{INTRODUCTION}

The dithiocarbamate family of chemicals is mainly used in agriculture and forms a large group of synthetic organic compounds that have been developed and used worldwide over the last 50 years. Dithiocarbamates are used as fungicides ${ }^{1}$, a few have been used as herbicides and soil insecticides. In industry, they are used as slimicides in water-cooling system, in paper manufacturing and as vulcanization accelerators and antioxidants in rubber ${ }^{2}$.

Exposure occurs mainly by inhalation and percutaneous absorption under occupational conditions. The general population can be orally exposed via ingestion of residues from treated food ${ }^{3-8}$.

The general formula of dithiocarbamates is:<smiles>[R3]SC(=S)N([R1])[R]</smiles>

$\mathbf{R}_{1}, \mathbf{R}_{2}=\mathbf{H}$, alkyl, aryl, heteroaryl, alkylaryl

$\mathbf{R}_{3}=$ Benzoyl, $\boldsymbol{o}$ - $\boldsymbol{\text { -dichlorobenzoyl }}$

Depending on the types of amines used (primary or secondary) in the reaction with the carbon disulfid, in the synthesis, mono-or dialkyldithiocarbamates are formed.

There are many salts of alkyl compounds dithiocarbamates known that result from the reaction of dithiocarbamates with metals or their salts which are uses in a wide variety of areas'.
In spite of the growing interest in applications of dithiocarbamates, preparative methods available for their synthesis are still limited ${ }^{10}$. Well known routes for their synthesis (depicted in Scheme-I) include the reactions of (a) mercaptanes with isothiocyanates using suitable basic catalyst ${ }^{11}$, (b) amines and carbon disulfide followed by treatment with formaldehyde and other amines in presence of phosphate buffer ${ }^{12}$, (c) dialkyl amines, carbon disulfide, electron deficient olefin under one pot aqueous condition ${ }^{13}$.

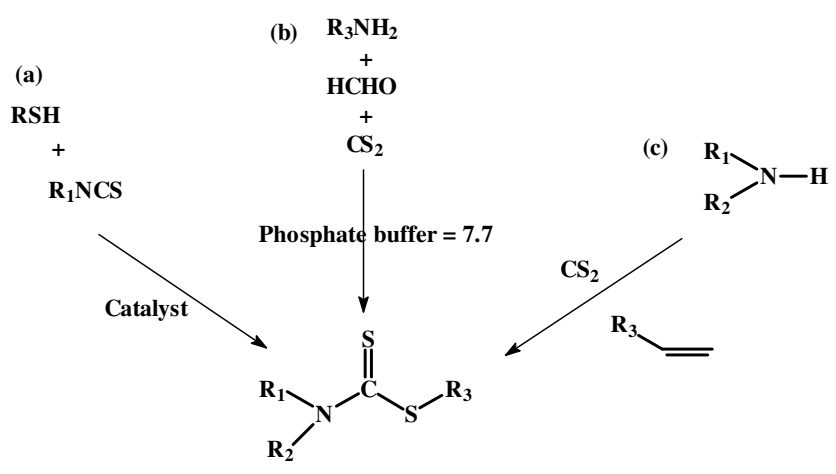

Scheme-I

However, all these synthetic methods are associated with one or the other limitations, such as low availability of starting material, or employment of harsh reaction conditions, high reaction temperature, long reaction times, low yields and two or more steps ${ }^{14}$. Due to the above mentioned facts and 
reasons, the synthesis of the dithiocarbamates in one-pot reaction from dialkylamines, carbon disulfide, phenacylbromide in presence of anhydrous sodium acetate, because this method is safe, high yield, short time reaction, low reaction temperature and availability of raw material. Scheme-II shows the general reaction equation.

$$
\begin{aligned}
& \underset{\mathrm{R}_{2}}{\mathrm{R}_{1}}{ }^{\mathrm{N}}-\mathrm{H}+\mathrm{CS}_{2}+{ }_{\mathrm{Ar}} \|_{\substack{\mathrm{C} \\
\mathrm{H}_{2}}}^{\mathrm{O}} \overbrace{}^{\mathrm{Br}}
\end{aligned}
$$

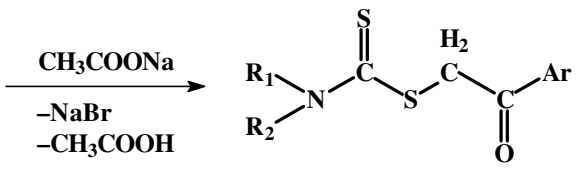

$$
\begin{aligned}
& \mathbf{R}_{1}, \mathbf{R}_{2}=\mathrm{C}_{4} \mathrm{H}_{9} ; \mathrm{Ar}=-\mathrm{C}_{6} \mathrm{H}_{5},-\mathrm{C}_{6} \mathrm{H}_{3} \mathrm{Cl}_{2}
\end{aligned}
$$

Scheme-II

In this paper, we reported the synthesis of N-dibutyldithiocarbamate, which contains the $\mathrm{CH}$-acid group and electron accepting group such as sulfur group and then studied the reaction of these compounds with carbon disulfide in the liquid heterogeneous phase, to give derivatives of dibutyldithiocarbamate and sodium dithiocarbamate salt.

\section{EXPERIMENTAL}

Glassware were cleaned and dried in the dryer (Ecocell) at $100^{\circ} \mathrm{C}$ before use. Solvents were evaporated under reduced [9R-125-B:491(Büchi)] at temperature $<45^{\circ} \mathrm{C}$. Thin layer chromatography (TLC) was performed using siliga gel 60F254 plates with $I_{2}$ vapours as detecting agents followed by spraying with Draggendorff reagent. TMS was used as an internal standard in ${ }^{1} \mathrm{H} \mathrm{NMR}$ in $\mathrm{CDCl}_{3}$. Infrared spectra were recorded as $\mathrm{KBr}$ pellets by FT/IR-400 (Jasco) spectrometer. Melting points were determined on a melting point apparatus. Unless chemicals were obtained with high purity from (Merck, Panreac, Sep) and were used without further purification.

General procedure for the preperation of phenacylbromide: Into a $500 \mathrm{~mL}$ three-necked flask with stirrer, reflux condenser, dropper funnel dropwise and calcium chloride tube was added to a solution of $0.5 \mathrm{~mol}$ acetophenone in $100 \mathrm{~mL}$ glacial acetic acid with a few drops of hydrogen bromide/ glacial acetic acid and dropped $0.5 \mathrm{~mol}$ of bromine to be increased so that the temperature maintained at $c a .20^{\circ} \mathrm{C}$ (at first reaction can occur in transition). When it is cooled in ice water. If no one is crystallizing, it poured into ice water. The solid compounds extracted and washed with $50 \%$ alcohol until they are colourless. It crystallized from alcohol to pure crystalline compound.

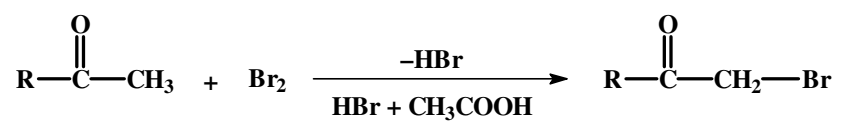

Preparation of di butyl-dithiocarbamates sodium salts $\left(\mathbf{C}_{9} \mathbf{H}_{18} \mathbf{N S}_{2} \mathbf{N a}\right)$ (1a): Into a $250 \mathrm{~mL}$ two-necked flask with stirrer, dropwise is added of $100 \mathrm{mmol}(12.9 \mathrm{~g})$ di-butylamine,
$100 \mathrm{mmol}$ sodium hydroxide $(4 \mathrm{~g})$ in $175 \mathrm{~mL}$ pure methanol and is added dropwise $100 \mathrm{mmol}$ of carbon disulfide $(7.6 \mathrm{~g}$, $6.022 \mathrm{~mL}$ ) to the stirred reaction mixture at room temperature. After finished adding $\mathrm{CS}_{2}$ stirring is continued for $1 \mathrm{~h}$. Then the reaction mixture is or was left to the next day and then is evaporated. The di butyl- dithiocarbamates sodium salts is formed.

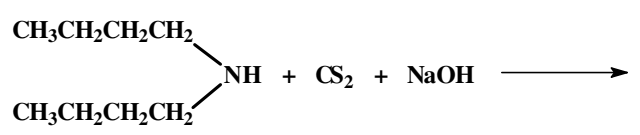<smiles>CCCCN(CCCC)C(=S)S[NH3+]</smiles>

Spectral data of compound 1a: As yellow solid, yield $80 \%$, m.p. $50{ }^{\circ} \mathrm{C}$, Ms $227 \mathrm{~g} / \mathrm{mol}$; IR (KBr, $v_{\max }, \mathrm{cm}^{-1}$ ): 3100 , 2850, 1464, 1367, 1250, 924, 543. ${ }^{1} \mathrm{H} \mathrm{NMR}\left(300 \mathrm{MHz}, \mathrm{CDCl}_{3}\right)$ : $\delta=0.98\left(\mathrm{~m}, 2\left(-\mathrm{CH}_{3}\right)\right.$ of $\left.\mathrm{C}_{4} \mathrm{H}_{9}\right), 1.26-1.58\left(\mathrm{~m}, 2\left(-\mathrm{CH}_{2}-\right)\right.$ near of- $\left.\mathrm{CH}_{3}\right), 1.62-1.68\left(\mathrm{~m}, 2\left(-\mathrm{CH}_{2}^{-}\right)\right), 4.28\left(\mathrm{~s}, 2\left(-\mathrm{CH}_{2}-\right)\right.$ near of N) ppm.

Preparation of phenacyl-dibutyl-dithiocarbamates $\left(\mathbf{C}_{\mathbf{1 7}} \mathbf{H}_{25} \mathbf{N O S}_{2}\right)$ (1b): To a solution of $103 \mathrm{mmol}$ (8.45 g) anhydrous sodium acetate, $103 \mathrm{mmol}(13.287 \mathrm{~g}, 17.529 \mathrm{~mL})$ dibutyl amine as the secondary amine and $103 \mathrm{mmol}(10.18 \mathrm{~g})$ carbon disulfide in $175 \mathrm{~mL}$ of absolute methanol was added dropwise $103 \mathrm{mmol}(20.5 \mathrm{~g})$ of an alkylating agent as phenacylbromide in $50 \mathrm{~mL}$ of absolute methanol. The solution left overnight at room temperature. Wherein the phenacyl-dialkyl-dithiocarbamates precipitate. The precipitate was filtered off and washed several times with a little water to separate sodium halide.

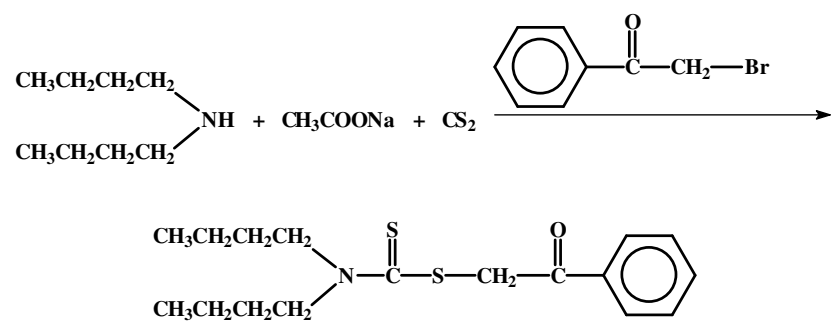

Spectral data of compound 1b: As blancsale solid, yield $81.7 \%$, m.p. $49.2{ }^{\circ} \mathrm{C}$, Ms $323 \mathrm{~g} / \mathrm{mol}$; IR $\left(\mathrm{KBr}, v_{\max }, \mathrm{cm}^{-1}\right)$ : $3050,2850,1750,1600,1484,1351,1207,1100,744 .{ }^{1} \mathrm{H}$ NMR $\left(300 \mathrm{MHz}, \mathrm{CDCl}_{3}\right): \delta 0.98\left(\mathrm{~m}, 2\left(-\mathrm{CH}_{3}\right)\right.$ of $\left.\mathrm{C}_{4} \mathrm{H}_{9}\right), 1.43-$ $1.9\left(\mathrm{~m}, 4\left(-\mathrm{CH}_{2}^{-}\right)\right.$of $\left.\mathrm{C}_{4} \mathrm{H}_{9}\right), 3.7-3.9\left(\mathrm{~m}, 2\left(-\mathrm{CH}_{2^{-}}\right)\right.$near of $\left.\mathrm{N}\right)$, $4.88\left(\mathrm{~s},\left(-\mathrm{CH}_{2-}\right)\right), 7.2-8.07\left(\mathrm{~m},-\mathrm{C}_{6} \mathrm{H}_{5}\right) \mathrm{ppm}$.

Preparation of (1-benzoyl-2,2-dibutylthio)vinyldibutyldithiocarbamates $\left(\mathrm{C}_{26} \mathbf{H}_{41} \mathbf{N O S}_{4}\right)(\mathbf{1 c})$ : To a solution of $5 \mathrm{mmol}(1.48 \mathrm{~g})(\mathbf{1 b})$ in $5 \mathrm{~mL}$ carbon disulfide and $5 \mathrm{~mL}$ chloroform is added with efficient stirring a mixture of 20 mmol $(1.12 \mathrm{~g})$ potassium hydroxide and $10 \mathrm{mmol}(2.3 \mathrm{~g})$ triethylbenzyl ammonium chloride (TEBA chloride) in $10 \mathrm{~mL}$ water. After $10 \mathrm{~min}$ at room temperature $15 \mathrm{mmol}(2.5 \mathrm{~mL})$ butyl iodide is added dropwise and stirring is continued for $1 \mathrm{~h}$. The phases are separated and the organic layer is washed with water and dried over anhydrous calcium chloride. The 
residue obtained by evaporation of the solvent is recrystallized from diethyl ether.

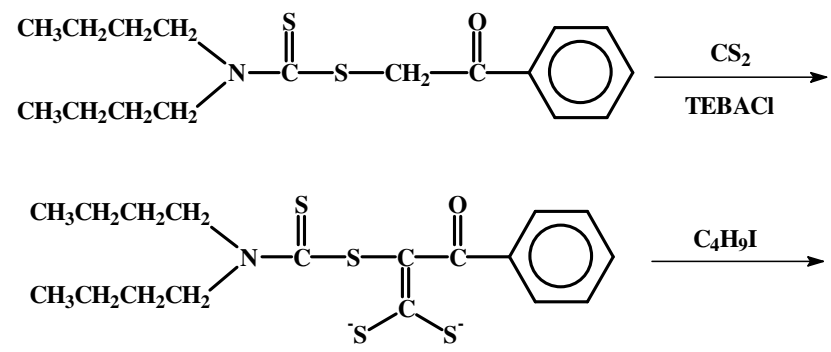<smiles>CCCCCCC(CCCCC)=C(SC(=S)N(CCCC)CCCC)C(=O)c1ccccc1</smiles>

Spectral data of compound 1c: As white solid, yield $77.3 \%$, m.p. $55^{\circ} \mathrm{C}$, Ms $511 \mathrm{~g} / \mathrm{mol}$; IR $\left(\mathrm{KBr}, \nu_{\max }, \mathrm{cm}^{-1}\right): 3080$, 2850, 1750, 1650, 1629, 1464, 1407, 1207, 1110, 739. ${ }^{1} \mathrm{H}$ NMR $\left(300 \mathrm{MHz}, \mathrm{CDCl}_{3}\right): \delta 1.24-1.27\left(\mathrm{~m}, 4\left(-\mathrm{CH}_{3}\right)\right.$ of $\left.4-\mathrm{C}_{4} \mathrm{H}_{9}\right)$, 1.302-1.94 (m, $8\left(-\mathrm{CH}_{2^{-}}\right)$of $\left.\mathrm{C}_{4} \mathrm{H}_{9}\right), 3.64-3.69\left(\mathrm{~m}, 2\left(-\mathrm{CH}_{2^{-}}\right)\right.$ near of S), 3.914-3.996 (m, $2\left(-\mathrm{CH}_{2}-\right)$ near of $\left.\mathrm{N}\right), 7.285$ $\left(-\mathrm{C}_{6} \mathrm{H}_{5}\right) \mathrm{ppm}$.

\section{REFERENCES}

1. R.K. Mishra, R.K. Tewari, S.K. Srivastava and S.C. Bahel, Asian J. Chem., 4, 412 (1992).

2. A.N. Pudovik, V.K. Khairullin, A.V. Il'yasov, M.A. Vasyanina, I.A. Aleksandrova, I.E. Ismayev and V.I. Ovcharov, Polym. Sci. U.S.S.R., 30, 475 (1988).

3. Environmental Health Criteria 142, Permethrin, Geneva, World Health Organization (1992).

4. Environmental Health Criteria 97, Deltamethrin, Geneva, World Health Organization (1990).

5. Environmental Health Criteria 95, Fenvalerate, Geneva, World Health Organization (1990).

6. H. Kidd and D.R. James, The Agrochemicals Handbook, Surrey, The Royal Society of Chemistry, edn. 3 (1991).

7. C.R. Worthing and R.J. Hance, The Pesticide Manual, Surrey, British Crop Protection Council, edn. 9 (1991).

8. F. He, J. Sun, K. Han, Y. Wu, P. Yao, S. Wang and L. Liu, Br. J. Ind. Med., 45, 548 (1988).

9. Alain Pelfrene Associated Consultants (APAC), A.F. Pelfrene, 5 Avenue Louis Momet F-69260 Charbonniers France: Chapter 3. Biological Monitoring of Selected Pesticides, pp. 123-165.

10. Y. Nishiyama, K. Tokunaga, H. Kawamatsu and N. Sonoda, Tetrahedron Lett., 43, 1507 (2002).

11. H. Ulirich, B. Tucker and A.A.R. Sayigh, J. Org. Chem., 32, 3938 (1967).

12. D. Katiyar, V.K. Tiwari, R.P. Tripathi, A.K. Srivastava, V. Chaturvedi, R. Srivastava and B.S. Srivastava, Bio. Org. Med. Chem., 11, 4369 (2003).

13. N. Azizi, F. Aryanasab, L. Torkiyan, A. Ziyaei and M.R. Saidi, J. Org. Chem., 71, 3634 (2006).

14. V.K. Tiwari, A. Singh, H.A. Hussain, B.B. Mishra and V. Tripathi, Monatsh. Chem., 138, 653 (2007). 